\title{
EFFECT OF TEMPERATURE-STRAIN PARAMETERS ON THE STRUCTURE AND MECHANICAL PROPERTIES OF Nb, V, Ni - ALLOYED STEELS IN TERMS OF HIGH TEMPERATURE THERMOMECHANICAL PROCESSING
}

\author{
Andrei RUDSKOI ${ }^{1}$, Georgii KODZHASPIROV ${ }^{1 a}$, Jiri KLIBER ${ }^{2}$ \\ ${ }^{1}$ Peter the Great St. Petersburg Polytechnic University, St. Petersburg, Russian Federation, \\ agkodzhaspirov@gmail.com \\ ${ }^{2}$ VSB - Technical University of Ostrava, Ostrava, Czech Republic, EU
}

https://doi.org/10.37904/metal.2019.680

\section{Abstract}

The effect of rolling temperature $\left(800-1000{ }^{\circ} \mathrm{C}\right.$ ) - strain accumulation (number of rolling passes: $\left.3 \div 5\right)$ - cooling rate $\left(8.6-25^{\circ} \mathrm{C} / \mathrm{s}\right)$ parameters at the High Temperature Thermomechanical Processing (HTMP) on the microstructure, mechanical properties at the room and low temperatures of $\mathrm{C}-\mathrm{Ni}-\mathrm{Nb}$ and $\mathrm{C}-\mathrm{Ni}-\mathrm{V}$ steels intended for the usage as a high- strength material for production of the shelf constructions, strips and other special welded products has been studied. Experiment planning method (EPM) has been used to study the effect of the mentioned above parameters on the mechanical properties. By results of experiments the regression equations described the qualitative and quantitative effect of HTMP parameters on the mechanical properties of steel are constructed. The analysis of microstructure and SEM analysis of the fracture at $+20^{\circ} \mathrm{C}$ and $-40^{\circ} \mathrm{C}$ temperatures has been carried out. It was shown that the highest strength ( $\mathrm{YS}=987 \mathrm{MPa}$ ) in combination with a high impact strength $(\mathrm{W}=154 \mathrm{~J})$ has a Ni-Nb-bearing steel with lower bainite structure formed result in maximum passes and highest deformation temperature and cooling rate realization. The best cold resistance has steel with low bainite structure transformed at the accelerate cooling from the fine fragmented hot deformed austenite.

Keywords: Mechanical properties, HSLA steels, rolling, microstructure, fracture

\section{INTRODUCTION}

It is known that HTMP is one of the most effective processes which resulting the optimum combination of strength, plasticity, fracture toughness and ductility of HSLA type steels [1-4]. Efficiency of influence of such treatment on the structure and mechanical properties is caused by the structural and phase transformations taking place during deformation, and at the cooling after deformation of hot deformed austenite as well. It is well known that $\mathrm{Nb}$ and $\mathrm{V}$ suppress the recrystallisation of austenite during and after rolling and refine the microstructure of HSLA steels with the beneficial effects on strength and cool resistance. Development of the manufacturing processing of the rolled plates from perspective $\mathrm{Ni}$, $\mathrm{Nb}$, $\mathrm{V}$-bearing steels for the high strength and cold resistance purposes with various mechanical properties generate a need for the study the effect of rolling scheduled followed by controlled cooling rate parameters on the structure formation such type steel grades at the conditions simulated the industrial rolling for the purpose to predict and to reach the desirable properties. Such investigations are desirable need to carry out in the laboratory rolling mill conditions simulated the industrial rolling as much as possible [5].

\section{EXPERIMENTAL PROCEDURE}

The objective of the present work is to study the effect of the most important HTMP parameters to the structure and mechanical properties of $\mathrm{Ni}, \mathrm{Nb}$ and $\mathrm{V}$ - bearing HSLA type steels. Two melts were produced in the 100 $\mathrm{kg}$ induction furnace. The chemical composition of steels are presented in Table 1.

Two melts were produced in the $100 \mathrm{~kg}$ induction furnace. The chemical composition of steels are presented in Table 1. 
Table 1 Chemical composition of $\mathrm{Ni}-\mathrm{Nb}$ and $\mathrm{Ni}-\mathrm{V}$ steels in wt. \%

\begin{tabular}{|c|c|c|c|c|c|c|c|c|c|c|}
\hline Steel & $\mathbf{C}$ & $\mathbf{S i}$ & $\mathbf{M n}$ & $\mathbf{S}$ & $\mathbf{P}$ & $\mathbf{N i}$ & $\mathbf{V}$ & $\mathbf{N b}$ & $\begin{array}{c}\mathbf{A r}_{3} \\
\left({ }^{\circ} \mathbf{C}\right)\end{array}$ & $\begin{array}{c}\mathbf{A r}_{1} \\
\left({ }^{\circ} \mathbf{C}\right)\end{array}$ \\
\hline $\mathrm{Ni}-\mathrm{Nb}$ & 0.09 & 0.31 & 0.52 & 0.003 & 0.003 & 1.39 & - & 0.03 & 775 & 651 \\
\hline $\mathrm{Ni}-\mathrm{V}$ & 0.07 & 0.18 & 0.32 & 0.006 & 0.008 & 1.03 & 0.02 & - & 803 & 654 \\
\hline
\end{tabular}

The laboratory hot rolling was carried out on mill "210" of Peter the Great St. Petersburg Polytechnic University for simulation temperature-strain-cooling rate conditions of deformation in the finished passes on the industrial rolling mill "5000". Specimens $450 \mathrm{~mm}$ long, and $75 \times 37 \mathrm{~mm}$, machined from hot rolled and annealed pieces were heated in an electrical oven for $90 \mathrm{~min}$. at $1200{ }^{\circ} \mathrm{C}$ and ten rolled in the mill according to the programs designed by experimental plan. The microstructure investigations were done prepared perpendicular to the rolling axis. Fracture analysis investigations of the samples tested at $+20^{\circ} \mathrm{C} ;-20^{\circ} \mathrm{C} ;-40{ }^{\circ} \mathrm{C}$ temperatures were carried out on the "PSEM-500".

Applying to $\mathrm{Ni}-\mathrm{Nb}$ steel experimental planning method of type $2^{3}$ has been realized [6]. Varied parameters of HTMP were the finished deformation temperature $\left(T_{f}=1000 \div 800^{\circ} \mathrm{C}\right)$, number of passes $(n=3 \div 5)$, and cooling rate followed by deformation corresponds air and water cooling $\left(\mathrm{V}_{\text {cool }}=8.6 \div 25^{\circ} \mathrm{C} / \mathrm{s}\right)$. The total strain degree $(\varepsilon \Sigma \sim 70 \%=$ const. $)$, Figure 1.

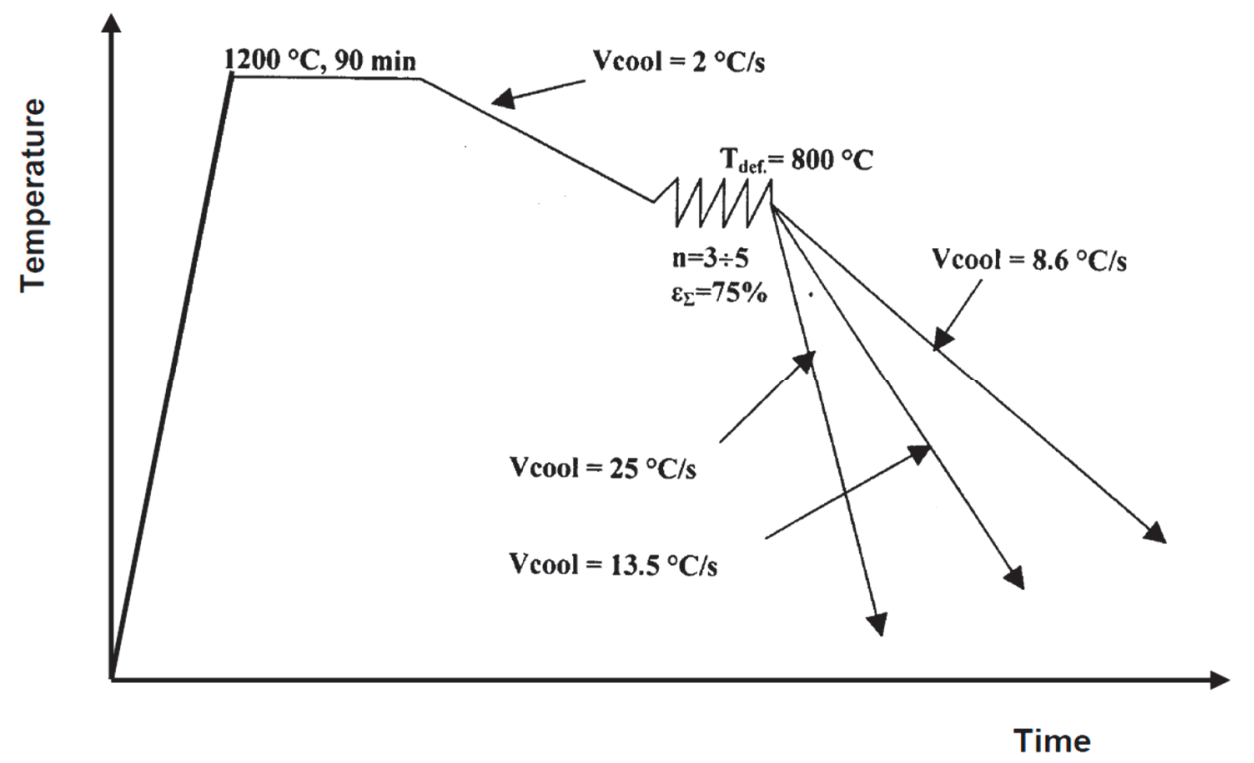

Figure 1 Schematic representation of simulated rolling schedules

The results of the mechanical tests (YS, TS, A, RA, KCV) are given in Table 2, varied which parameters are submitted in Table 2.

\section{RESULTS AND DISCUSSION}

As a result of data processing by methods regression and dispersion analyses the regression equations of have been constructed:

$$
\begin{aligned}
& Y_{1}=647.2+44.78 X_{1}+47.78 X_{2}+161.60 X_{3} \\
& Y_{2}=865.0+24.10 X_{1}+26.2 X_{2}+186.73 X_{3} \\
& Y_{3}=18.65+0.16 X_{1}+0.11 X_{2}-4.4 X_{3} \\
& Y_{4}=70.2+0.005 X_{1}+0.006 X_{2}+1.95 X_{3}
\end{aligned}
$$




$$
\begin{aligned}
& X_{1}=\left(T_{f}-900\right) / 100 ; \\
& X_{2}=(n-4) / 1 ; \\
& X_{3}=\left(V_{\text {cool }}-16.8\right) / 8.4
\end{aligned}
$$

where:

\begin{tabular}{|c|c|c|c|c|c|c|c|c|c|c|}
\hline \multirow[t]{3}{*}{ Test no. } & \multicolumn{3}{|c|}{ HTMP parameters } & \multicolumn{7}{|c|}{ Mechanical properties } \\
\hline & \multirow{2}{*}{$\begin{array}{c}\mathrm{T}_{\mathrm{f}} \\
{ }^{\circ} \mathrm{C} \\
\left(\mathrm{X}_{1}\right)\end{array}$} & \multirow{2}{*}{$\begin{array}{c}\mathbf{N} \\
\overline{\left(X_{2}\right)}\end{array}$} & \multirow{2}{*}{$\begin{array}{l}\mathrm{V}_{\text {cool }} \\
{ }^{\circ} \mathrm{C} / \mathrm{s} \\
\left(\mathrm{X}_{3}\right)\end{array}$} & \multirow{2}{*}{$\begin{array}{l}\mathrm{YS} \\
\mathrm{MPa} \\
\left(\mathrm{Y}_{1}\right)\end{array}$} & \multirow{2}{*}{$\begin{array}{l}\text { TS } \\
\text { MPa } \\
\left(Y_{2}\right)\end{array}$} & \multirow{2}{*}{$\begin{array}{c}A \\
\% \\
\left(Y_{3}\right)\end{array}$} & \multirow{2}{*}{$\begin{array}{c}\text { RA } \\
\% \\
\left(Y_{4}\right)\end{array}$} & \multicolumn{3}{|c|}{$\mathrm{KCV}, / \mathrm{KV}^{*},\left(\mathrm{~kJ} / \mathrm{m}^{2}\right) / \mathrm{J}$} \\
\hline & & & & & & & & $+20^{\circ} \mathrm{C}$ & $-20^{\circ} \mathrm{C}$ & $-40^{\circ} \mathrm{C}$ \\
\hline 1 & 1000 & 5 & 25 & 988 & 1193 & 12 & 72 & $\frac{1776}{142}$ & $\frac{1668}{133}$ & $\frac{1246}{100}$ \\
\hline 2 & 1000 & 5 & 8.6 & 465 & 670 & 25 & 69 & $\frac{471}{38}$ & $\frac{294}{20}$ & $\frac{128}{10}$ \\
\hline 3 & 800 & 5 & 25 & 821 & 1020 & 15 & 73 & $\frac{1501}{120}$ & $\frac{1040}{83}$ & $\frac{510}{41}$ \\
\hline 4 & 800 & 5 & 8.6 & 512 & 688 & 23 & 67 & $\frac{500}{40}$ & $\frac{216}{17}$ & $\frac{157}{13}$ \\
\hline 5 & 1000 & 3 & 25 & 798 & 1012 & 17 & 72 & $\frac{2267}{181}$ & $\frac{893}{71}$ & $\frac{206}{17}$ \\
\hline 6 & 1000 & 3 & 8.6 & 522 & 687 & 21 & 68 & $\frac{893}{71}$ & $\frac{294}{24}$ & $\frac{157}{13}$ \\
\hline 7 & 800 & 3 & 25 & 632 & 987 & 13 & 71 & $\frac{1172}{94}$ & $\frac{978}{784}$ & $\frac{148}{12}$ \\
\hline 8 & 800 & 3 & 8.6 & 451 & 674 & 23 & 70 & $\frac{922}{74}$ & $\frac{265}{21}$ & $\frac{137}{11}$ \\
\hline
\end{tabular}

$Y_{1}$ - yield strength; $Y_{2}$ - tensile strength; $Y_{3}$ - elongation; $Y_{4}$ - reduction of area - optimization parameters.

Table 2 Mechanical properties of HTMP treated Ni-Nb steel

Judging from the value of regression coefficients, varied parameters on a degree of the importance can be arranged in the following sequence: $V_{\text {cool }}$ - cooling rate after deformation; $\mathrm{n}$ - deformation passes; $\mathrm{t}_{\mathrm{f}}$ - finished deformation temperature.

As follows from the results of mechanical tests, maximal strength characteristics (YS $=987( \pm 8) \mathrm{MPa}$ ) have the samples subjected HTMP by regime 1, providing a maximum of temperature of the finished deformation temperature $\left(1000^{\circ} \mathrm{C}\right)$, numbers of passes and cooling rate (see the Table 2, Figure 2). The reason is the formation of dispersed low bainite structure, resulting from the fragmented initial (before transformation) hot deformed austenite (Figure 3a). Dispersion of the hot deformed austenite at the fractional deformation is detail described in [6]. In case of fractional deformation for five passes decrease of the $T_{f}$ from 1000 up to $800^{\circ} \mathrm{C}$ results in occurrence in structure of the sites pearlite and free ferrite (Figure $\mathbf{3 b}$ ). It is result in the lowering of $T_{f}$ below $A_{r 3}$ that results in decrease of strength. Decrease of the passes number from 5 to 3 is accompanied by the further insignificant lowering strength characteristics - an the average of $20-25 \%$. It can be result in the lesser crystal lattice defects density and formed less fine structural components (bainite, pearlite, ferrite) size in compare with deformation for five passes.

The formed result in phase transformation low bainite show evidence of hereditary of the fragmented hot deformed austenite be coordinated to the data of [6]. Air cooling is changes the structure radically and, correspondingly, mechanical properties of steel. The basic structures as a result of diffusive transformations of austenite are ferrite and pearlite (Figure 3c). However the pearlite colonies and ferrite grains sizes, and also their ratio, depend from HTMP regimes: at $n=5$ grain sizes corresponds to $15-22 \mu \mathrm{m}$, and at $n=3$ to $31-41 \mu \mathrm{m}$. Result in three passes rolling the highest strength characteristics (YS $=798( \pm 10) \mathrm{MPa})$ has steel 
after HTMP by mode $n o .5$ (Table 2$)$ with the $T_{f}\left(1000^{\circ} \mathrm{C}\right)$ followed by water cooling (Table 2$)$. The less value in compare with 5 passes deformation most probably be associated with the formation of bainite structures, rather more rough, than formed result in HTMP with $n=5$.

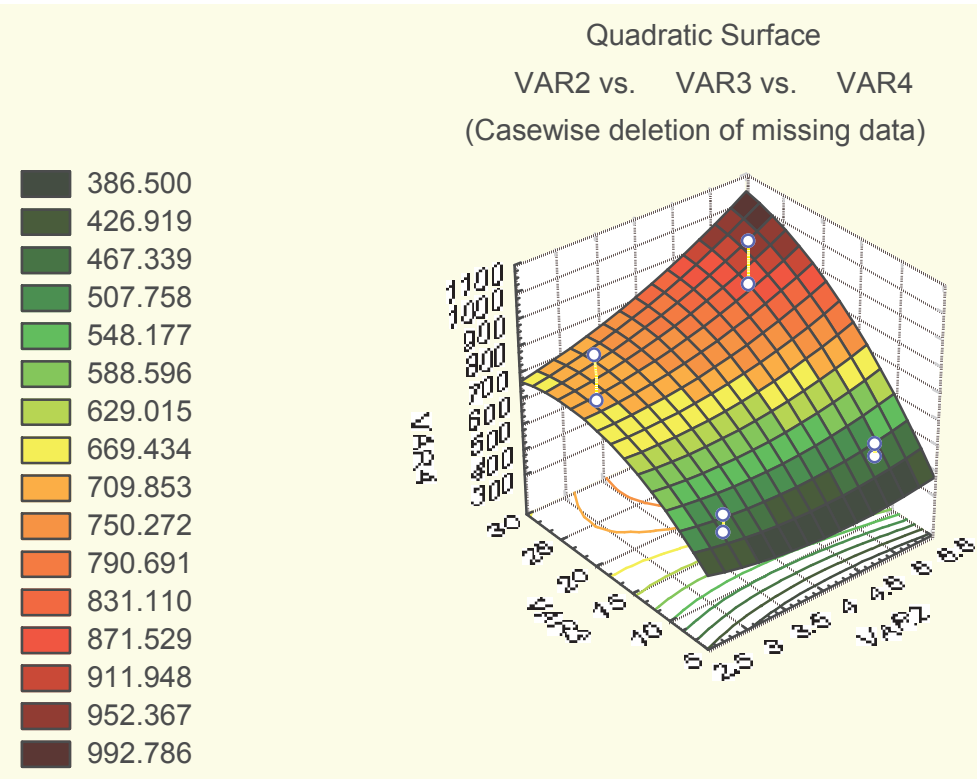

Figure 2 Yield Strength, MPa (VAR4) - number of passes (VAR2) and cooling rate ${ }^{\circ} \mathrm{C} / \mathrm{s}$ (VAR3) - relationship
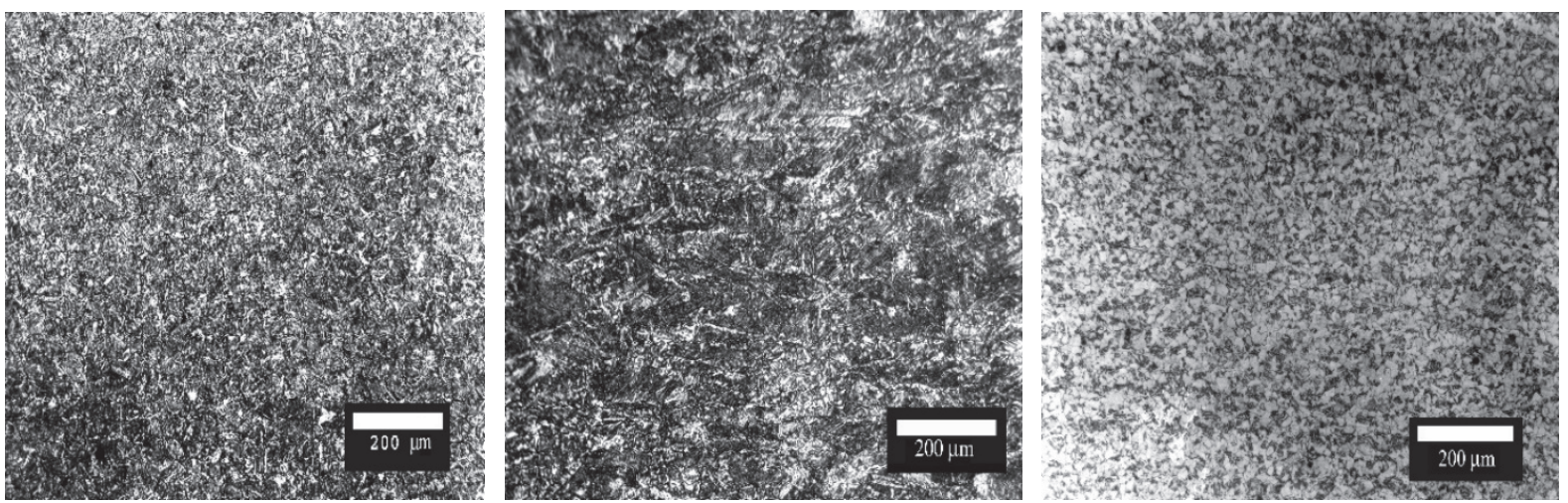

Figure 3 Microstructure of $\mathrm{Ni}-\mathrm{Nb}$ steel after HTMP according to regimes: $\mathrm{T}_{f}=1000^{\circ} \mathrm{C}, \mathrm{n}=5$, $V_{\text {cool }}=25^{\circ} \mathrm{C} / \mathrm{s}(\mathrm{a}), \mathrm{T}_{\mathrm{f}}=800^{\circ} \mathrm{C}, \mathrm{n}=5, \mathrm{~V}_{\text {cool }}=25^{\circ} \mathrm{C} / \mathrm{s}(\mathrm{b}), \mathrm{T}_{\mathrm{f}}=1000^{\circ} \mathrm{C}, \mathrm{n}=5, \mathrm{~V}_{\text {cool }}=8.6^{\circ} \mathrm{C} / \mathrm{s}$ (c)

The least $(\mathrm{YS}=450( \pm 7) \mathrm{MPa})$ strength characteristics has steel processed on a mode 8 (Table 2). The last results it is possible to explain with excessively low $T_{f}\left(\right.$ below $\left.A_{r 3}\right)$ such that a some part of deformed austenite decomposition takes place. The highest in compare with mode 2 pearlite colonies size testifies probably is responsible for the mentioned above.

Some rise of YS result in number of passes increasing in a case $T_{f}=800^{\circ} \mathrm{C}$ it is possible to explain by coldwork of the ferrite formed at cooling is lower than $A_{r 3}$. Similar correlation was observed in $[5,6]$ in the middle carbon steels. Characteristics of plasticity change in inverse proportion.

The highest effect of the cooling rate on the mechanical properties has a simple explanation. The increase of $V_{\text {cool }}$ result in the metastable (like bainite) products of the hot deformed austenite transformation formation and correspondingly - increasing of the strength and decrease of plastic characteristics. 
Estimation of cold resistance was carried out by the results of impact strength evaluation at temperatures from +20 to $-40^{\circ} \mathrm{C}$. It was established that the greatest cold resistance $\mathrm{Nb}$-bearing steel has at the highest values of the studying parameters: 5 rolling passes, deformation temperature $1000{ }^{\circ} \mathrm{C}$ and cooling rate $25^{\circ} \mathrm{C} / \mathrm{s}$. The least cold resistance has steel with low followed by the deformation cooling rate (air cooling). Such results are explained by the best cold resistance of bainite structures in compare with pearlite structures.

Fracture of the samples water cooled at HTMP and tested at $+20^{\circ} \mathrm{C}$ are ductile (Figure 4a). The width of a crack origin zone is $\sim 300 \mu \mathrm{m}$. At decrease of the test temperature to $-20^{\circ} \mathrm{C}$ there are sites brittle transcrystalline fracture (up to $15 \%$ ) with the quasi-cleavage mechanism, and $85 \%$ ductile transcrystalline ones. As this takes place the crack origin zone width is decreases to $180 \mu \mathrm{m}$. The further decreasing of the test temperature up to $-40^{\circ} \mathrm{C}$ increases the area of brittle transcrystalline fracture up to $20 \%$ and the rest $80 \%$ is ductile transcrystalline fracture. Correspondingly the highest fracture energy capacity takes place in case of tests at $+20^{\circ} \mathrm{C}$, the least at $-40^{\circ} \mathrm{C}$. Fracture of the samples treated at HTMP with rolling followed by air cooling has another character. Namely, in case of tests at $+20^{\circ} \mathrm{C}$ fracture occurs by the quasi-cleavage mechanism, and the areas covered with of such type fracture making up $>00 \%$ of the fracture area. The rest part of the fracture has ductile transcrystalline fracture at crack width origin about $250 \mu \mathrm{m}$ (Figure 4b).

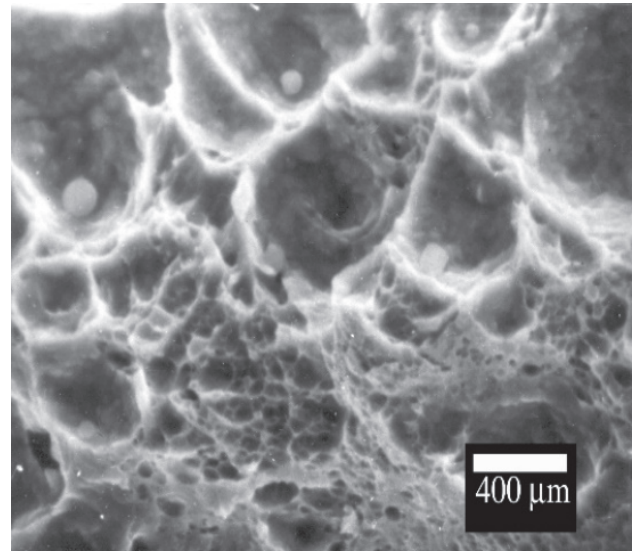

a)

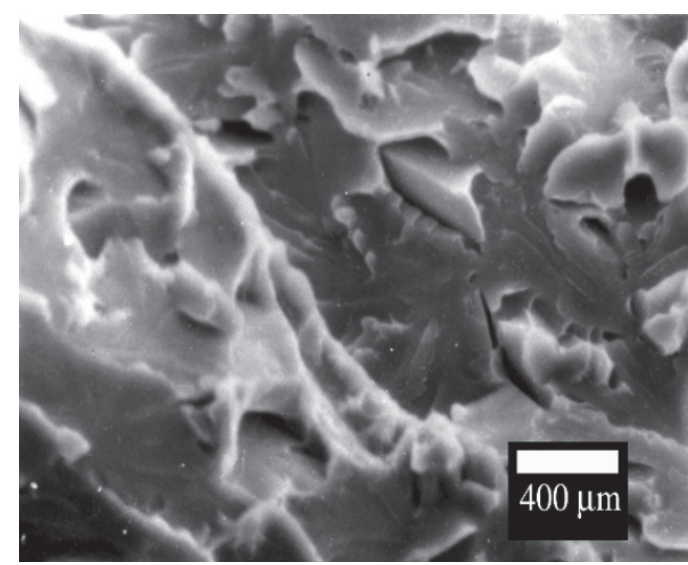

b)

Figure 4 Fracture of the Ni-Nb HTMP $\left(T_{f}=1000^{\circ} \mathrm{C}, n=5 ; V_{\text {cool. }}=25^{\circ}\right)$ treated steel at $+20^{\circ} \mathrm{C}(\mathrm{a})$, $-20^{\circ} \mathrm{C}(\mathrm{b})$, and $\left(\mathrm{T}_{\mathrm{f}}=1000{ }^{\circ} \mathrm{C}, \mathrm{n}=5 ; \mathrm{V}_{\text {cool. }}=8.6^{\circ} \mathrm{C}\right)$ at $+20^{\circ} \mathrm{C}$

The impact strength specimens tested at $-20^{\circ} \mathrm{C}$ have $100 \%$ quasi-cleavage type fracture with the crack origin zone width about a $450 \mu \mathrm{m}$. Lowering of the deformation temperature from 1000 to $800^{\circ} \mathrm{C}$ in case of HTMP with water cooling practically does not effect to the fracture type. Distinction consists only that after HTMP with $T_{f}=800^{\circ} \mathrm{C}$ there are semi-cleavage sites appear in the fracture result in ferrite-pearlite structure formation so as critical $A_{r 3}$ point of the steel is $776{ }^{\circ} \mathrm{C}$ alongside with a bainite component. The width a zone of the crack origin grows to $\sim 600 \mu \mathrm{m}$. At decrease of a testing temperature to $-40^{\circ} \mathrm{C}$ there is a sharp increase (up to $95 \%$ ) the brittle transcrystalline fracture mode component in the fracture. The last (5\%) part has ductile transcrystalline fracture mode result in the fracture energy consumption is essentially lowered.

HTMP by regime: $T_{f}=800^{\circ} \mathrm{C}, \mathrm{n}=5, \mathrm{~V}_{\text {cool }}=8.6^{\circ} \mathrm{C} / \mathrm{s}$ as it was mentioned before, results in ferrite-perlite structures formation and, correspondingly, to the lowering of the fracture energy consumption. Fracture of steel at test $=+20^{\circ} \mathrm{C}$ has, basically, quasi-cleavage character. Lowering of the test temperature to $-40^{\circ} \mathrm{C}$ causes formation of the cleavage regions alongside with quasi-cleavage regions. The width of the crack origin zone at $-40^{\circ} \mathrm{C}$ temperature test is about $\sim 80 \mu \mathrm{m}$.

To compare the effect of cooling rate the followed by the hot rolling at HTMP to the structure and mechanical properties applying to $\mathrm{Nb}$ and $\mathrm{V}$ - bearing steels it was realized an experiments in accordance with the scheme (Figure 1). The experiments was based upon the results of the mentioned applying $\mathrm{Nb}$-bearing steel results. 
Namely, deformation temperature $\left(1000^{\circ} \mathrm{C}\right)$ and number of passes $(n=5)$ were selected as a best to realize the best combination strength and ductility. Mechanical properties of Nb and V-bearing steels after HTMP with the different cooling rate are presented in Table 3.

Tests at $+20^{\circ} \mathrm{C}$ show the best combination of yield strength and cold resistance of both steels for the highest cooling rate, when the low bainite structure in the total volume of the samples takes place.

Table 3 Mechanical properties of HTMP treated Ni-Nb and Ni-V bearing steels

\begin{tabular}{|c|c|c|c|c|c|c|c|c|c|}
\hline \multirow{3}{*}{ Test no. } & \multirow{3}{*}{ Steel } & \multirow{3}{*}{$\begin{array}{l}\mathrm{V}_{\text {cool. }} \\
{ }^{\circ} \mathrm{C} / \mathrm{s}\end{array}$} & \multicolumn{7}{|c|}{ Mechanical properties } \\
\hline & & & \multirow{2}{*}{$\begin{array}{c}\text { YS } \\
\text { MPa }\end{array}$} & \multirow{2}{*}{$\begin{array}{c}\text { TS } \\
\mathrm{MPa}\end{array}$} & \multirow{2}{*}{$\begin{array}{l}A \\
\%\end{array}$} & \multirow{2}{*}{$\begin{array}{c}\text { RA } \\
\%\end{array}$} & \multicolumn{3}{|c|}{$\mathrm{KCV}\left(\mathrm{kJ} / \mathrm{m}^{2}\right)$} \\
\hline & & & & & & & $+20^{\circ} \mathrm{C}$ & $-20^{\circ} \mathrm{C}$ & $-40^{\circ} \mathrm{C}$ \\
\hline 1 & \multirow{3}{*}{$\mathrm{Ni}-\mathrm{Nb}$} & 8.6 & 293 & 463 & 31 & 66 & 687 & 152 & 69 \\
\hline 2 & & 13.5 & 379 & 547 & 25 & 63 & 517 & 288 & 197 \\
\hline 3 & & 25 & 501 & 645 & 18 & 62 & 615 & 239 & 199 \\
\hline 4 & \multirow{3}{*}{$\mathrm{Ni}-\mathrm{V}$} & 8.6 & 285 & 451 & 25 & 66 & 997 & 245 & 147 \\
\hline 5 & & 13.5 & 437 & 579 & 20 & 73 & 844 & 613 & 262 \\
\hline 6 & & 25 & 445 & 590 & 16 & 66 & 912 & 383 & 368 \\
\hline
\end{tabular}

$\mathrm{Nb}$ - bearing steel has a higher in compare with $\mathrm{V}$ - bearing strength, but impact strength at the negative testing temperatures is less.

\section{CONCLUSION}

1) HTMP treated to the low bainite structure steel has the highest resistance to brittle fracture. Low bainite finely divided structure is formed as a result of the hot deformed fragmented austenite - bainite transformation under accelerate cooling.

2) $\mathrm{Nb}$ - bearing steel has a higher in compare with $\mathrm{V}$ - bearing strength, but cold resistance is lower.

3) NiNb bearing steel with low bainite structure result in HTMP with maximal number of rolling passes, has the greatest strength properties.

\section{REFERENCES}

[1] JONAS, J.J., BARNETT, M.R., HODGSON, P.D. Thermomechanical Processing Materials. Eds. Groza, J.R., Shackelford, J.F., Lavernia, E.J. CRC Press: Boca Raton: 2007, 670 p. ISBN 978-0-8493-3216-6.

[2] DEARDO, A.J. New Challenges in the Thermomechanical Processing of HSLA Steels. Materials Science Forum. 2003, vol.426-432, pp.49-56.

[3] KODJASPIROV, G.E., KIM, I. Thermomechanical Processing of Steels. St. Petersburg State Technical University, 1998, $227 \mathrm{p}$.

[4] AleXANDROV, S., HULKA, K., STEPASHIN, A., MOROZOV, Y.U. In: High Technologies in Advanced Metal Science and Engineering. 2004, pp.38-48.

[5] KODJASPIROV, G.E., KARJALAINEN, L.P., SPEIDEL, M.O. Materials and Manufacturing Processes. 2004, vol.19, iss. 1, pp.87-94.

[6] KODJASPIROV, G.E., RYBIN, V.V., DRAKATOS, P.A. In: $2^{\text {nd }}$ Int. Conf. Thermomechanical Processing of Steels TMP. 2004. Liege, 2004, pp.349-355. 